\title{
SENSORY AND MICROBIOLOGICAL EVALUATION OF TILAPIA FISH IN PORT-SAID MARKETS
}

(With 3 Tables)

\author{
By
}

\section{TAGHREED A. HAFEZ and AMAL A. MEGAHED}

(Received at 13/9/2011)

التقييم الحسى والميكروبيولوجى لأسماك البلطى المباعة بأسواق بورسعيد

$$
\text { تغريي /حد حافظ ، /مل /حد مجاهد }
$$

تم فحص وتقييم •0 عينة من اسماك البلطى الطازجة المباعة باسواق بورسعيد. وقد تم التقبيم

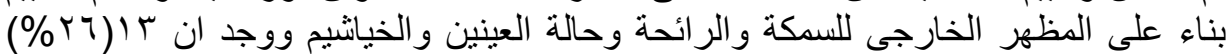

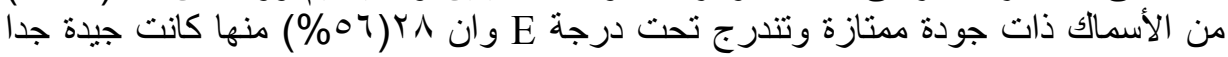

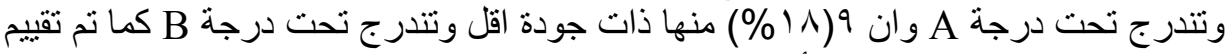

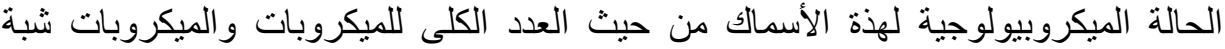

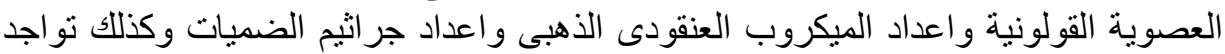

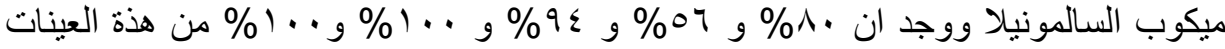

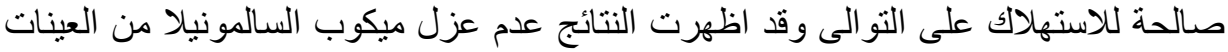

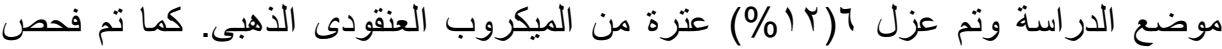

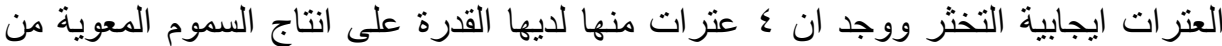

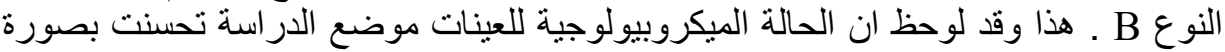

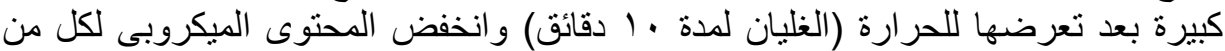

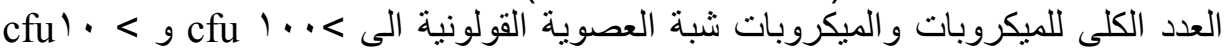

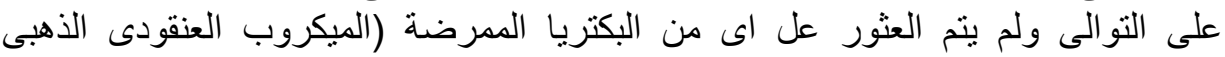
وجر اثيم الضميات وكذللك ميكوب السالمونيلا) فى العينات المعاملة حر اريا.

\section{SUMMARY}

The freshness and hygienic quality of 50 fresh Tilapia sold in Port-Said fish market were evaluated. Quality grades based on the sensory evaluation of general appearance, odor, texture and condition of eyes and gills showed that $26 \%$ of the examined Tilapia were of grade (E), the excellent quality followed by $56 \%$ of grade (A) and $18 \%$ of grade (B). The quality levels based on the microbial load, showed that the 
accepted percentage of samples for human consumption according to; total viable count (TVC), total coliform bacteria (TC), S.aureus count, total Vibrio spp. count and Salmonella spp. were; 80\%, 56\%, 94\%, $100 \%$, and $100 \%$ respectively. Salmonella could not be detected in any of the examined samples, only 6(12\%) of samples have S.aureus with mean count of $5.1 \times 10^{1} \pm 0.114 \mathrm{cfu} / \mathrm{g}$. Coagulase positive S.aureus was further examined for their ability to produce enterotoxins and only four isolates were found to be enterotoxin type $\mathrm{B}$ producers. The microbiological quality of fish was markedly improved by heat treatment (boiling for 10 minutes); The TVC, TC decreased to $<100 \mathrm{cfu} / \mathrm{g},<10 \mathrm{cfu} / \mathrm{g}$ respectively and no pathogenic bacteria (S.aureus, Salmonella and Vibrio spp.) could be detected in the treated samples.

Key words: Fish, Tilapia, S.aureus, Salmonella, Vibrio sp., freshness of fish.

\section{INTRODUCTION}

Fish is one of the most important source of animal protein supplement in the word. Recently, the demand of Tilapia fish consumption has been increased continuously because of its low price with high nutritive value. Moreover, Tilapia fish has many outstanding advantages such as; easy to culture, high growth rate, easy breeding, high fibrillar protein, good taste, white cotton meat and have more omega -3 fatty acid than other fresh water fishes (Aquatic Animal research Center Charoenpokphand 1999). Tilapia also grows well in brackish water attaining 200-350 g in 4-6 months (Romana-Eguia and Eguia 1999). Fish carries high microbial load on the surface of the skin, intestine and the gills. It has been well known that both fresh and brackish water fishes can harbor human pathogenic bacteria, particularly the Coliform group (Leung et al., 1990; Pulella et al., 1998; Ramos and Lyon 2000). Fish can also gain access bacteria during handling and transportation. In Egypt fish is sold in the open markets, the microbiological quality and safety of these street vended fish have always been contentious. Microorganisms are the major cause of spoilage of most sea food products (FAO, 1995), there is a direct relationship between the microbiological profile of food and its safety and quality. Microbiological quality evaluation of fish aims to quantify the hygienic quality of fish, including temperature abuse and the possible presence of pathogenic microorganisms in the fish. Some 
bacteria have the ability to produce toxins in the food such as the toxigenic strains of S.aureus such toxin could not be destroyed during cooking (heat labile) (Bruce and Kermit, 2009). Therefore, the present study was conducted to study the sensory and microbiological quality of Tilapia fish sold in Port-Said fish market and test the ability of the isolated bacterial strains for toxin production and evaluate the effect of heat treatment on the microbiological quality of the fish.

\section{MATERIALS and METHODS}

A total of 50 Tilapia fish samples were collected from Port-Said fish market. The samples were transported as soon as possible in polyethylene bags in ice tank to the laboratory for sensory and microbiological examination. Each sample was divided into two parts the first one was analyzed soon for sensory and bacteriological evaluation and the second one was boiled for 10 minutes and left to cool then analyzed bacteriologically.

\section{1- Sensory evaluation:}

Fresh samples were washed using potable water and presented whole to panel. Samples were examined physically for general appearance of skin, consistency of flesh, odor, color of the gills, color and condition of eyes and slime formation following the scheme provided by FAO (1995). The grading of fish was done according to Hall (1992)

\section{2- Bacteriological evaluation:}

Disinfection of the skin of fish was performed by $70 \%$ ethyle alcohol (luky1977), then twenty five grams of fleshly part were taken aseptically and homogenized with two hundred and twenty five $\mathrm{ml}$ of Butterfield's phosphate-buffered dilution water in a sterile stomacher bag. The 1:10 dilution in Butterfield's phosphate-buffered dilution water was further serially diluted to prepare decimal dilutions of $10^{-2}, 10^{-3}$, $10^{-4}$, and others as appropriate. Aerobic Plate Count (APC) agar was used for counting Total Viable count (TVC) according to FDA (2001a). Violet Red Bile Agar (VRBA) was used for counting total coliforms (TC) according to FDA (2002a). Baird-Parker agar for counting S.aureus according to FDA (2001b).

The isolation and identification of Salmonella was done according to FDA (2007). 25 gram of fish flesh were aseptically added to $225 \mathrm{ml}$ of lactose broth and homogenized in a stomacher for 2 
minutes. Aseptically transferred to sterile wide-mouth, screw-cap jar $(500 \mathrm{ml})$ or other appropriate container and let to stand $60 \pm 5 \mathrm{~min}$ at room temperature with jar securely capped. Loosen jar caps $1 / 4$ turn and incubated $24 \pm 2 \mathrm{~h}$ at $35^{\circ} \mathrm{C} .0 .1 \mathrm{ml}$ mixture was transferred to $10 \mathrm{ml}$ Rappaport-Vassiliadis (RV) medium and another $1 \mathrm{ml}$ mixture to $10 \mathrm{ml}$ tetrathionate (TT) broth. RV medium was incubated $24 \pm 2 \mathrm{~h}$ at $42 \pm$ $0.2^{\circ} \mathrm{C}$ and TT broth $24 \pm 2 \mathrm{~h}$ at $35 \pm 2.0^{\circ} \mathrm{C}$. The tubes were vortexed and streaked over, xylose lysine desoxycholate (XLD) agar, and Hektoen enteric (HE) agar. The plates were incubated at $35^{\circ} \mathrm{c}$ for 24 hours. Plates were examined for suspected Salmonella. Typical Salmonella colonies were subjected to biochemical and serological tests, when typical colonies were absent atypical Salmonella were picked and subjected to biochemical tests

Total Vibrio count was done according to (FDA 2004) 1:10 dilution was prepared by combining 50 gram of fish with $450 \mathrm{ml}$ of $2 \%$ $\mathrm{NaCl}$ in a sterile stomacher bag, Stomached for 2 minutes. tenfold dilution in $2 \% \mathrm{NaCl}$ was prepared and 3-tube were inoculated, multiple dilution, and MPN series using alkaline peptone water (APW) (i.e., added $1 \mathrm{ml}$ portions of each 1:10 and higher dilution to sets of 3 tubes containing $10 \mathrm{ml}$ APW). tubes incubated $16-18 \mathrm{~h}$ at $35^{\circ} \mathrm{C}$. The tubes were examined for turbidity. All dilutions showed visible turbidity were streaked plus the next highest (non-turbid) dilution, by taking a loopful of culture from the top $1 \mathrm{~cm}$ of each broth streaked onto thiosulphate and citrate bile salts agar (TCBS), incubated at $35^{\circ} \mathrm{C}$ for $18-24 \mathrm{~h}$. then examined for Vibrio spp. All suspected cultures were stained with Gram reagent and observed microscopically and biochemically. After suspect colonies are identified, apply MPN tables (Table) for recording final enumeration of Vibrio species.

\section{3- Detection of Staphylococcus aureus enterotoxins:}

Production of enterotoxins A, B, C, D, and TSST-1 was determined by a reverse passive latex agglutination kit (SET-RPLA, Oxoid) according to the manufacture's constructions. A colony of coagulase- positive S.aureus was cultured in $1 \mathrm{ml}$ of brain heart infusion broth and incubated at $37^{\circ} \mathrm{c}$ for $18-24$ hours. The culture was centrifuged and the supernatant was tested for enterotoxin production using a passive latex agglutination kit.

\section{RESULTS}

Table 1: Sensory evaluation of fresh Tilapia 
Assiut Vet. Med..J. Vol. 57 No. 131 October 2011

\begin{tabular}{|c|c|c|c|}
\hline Grade & No. of samples & Points & Degree of freshness \\
\hline E & $13(26 \%)$ & $>2.7$ & Excellent \\
\hline A & $28(56 \%)$ & 2 to 2.7 & Acceptable/Good \\
\hline B & $9(18 \%)$ & 1 to 2 & Borderline \\
\hline
\end{tabular}

Table2: Microbiological quality of fresh and heat treated Tilapia.

\begin{tabular}{|c|c|c|c|c|c|c|}
\hline & \multicolumn{3}{|c|}{ Fresh } & \multicolumn{3}{c|}{ Heat treated } \\
\cline { 2 - 7 } & Min. & Max. & Mean \pm SD & Min. & Max. & Mean \pm SD \\
\hline $\begin{array}{c}\text { Total viable } \\
\text { count }\end{array}$ & $2.5 \times 10^{1}$ & $4.6 \times 10^{8}$ & $4.2 \times 10^{6} \pm 0.002$ & $<10^{1}$ & $2.1 \times 10^{2}$ & $1.2 \times 10^{1} \pm 0.120$ \\
\hline $\begin{array}{c}\text { Coliform } \\
\text { count }\end{array}$ & $<10^{1}$ & $6.1 \times 10^{4}$ & $2.8 \times 10^{2} \pm 0.010$ & $<10^{1}$ & $1.4 \times 10^{1}$ & $0.6 \times 10^{1} \pm 0.103$ \\
\hline $\begin{array}{c}\text { S.aureus } \\
\text { count }\end{array}$ & $<10^{1}$ & $3.7 \times 10^{3}$ & $5.1 \times 10^{1} \pm 0.114$ & $<10^{1}$ & $<10^{1}$ & $<10^{1}$ \\
\hline $\begin{array}{c}\text { Total vibrio } \\
\text { count } \\
\text { (MPN) }\end{array}$ & $<10^{1}$ & $4.6 \times 10^{2}$ & $2.1 \times 10^{1} \pm 0.002$ & $<10^{1}$ & $<10^{1}$ & $<10^{1}$ \\
\hline \begin{tabular}{c} 
Salmonella \\
\hline
\end{tabular} & $\mathrm{ND}$ & $\mathrm{ND}$ & $\mathrm{ND}$ & $\mathrm{ND}$ & $\mathrm{ND}$ & $\mathrm{ND}$ \\
\hline
\end{tabular}

ND: Not detected

Table 3: Number and percentages of acceptable and unacceptable fresh Tilapia according to the microbiological quality

\begin{tabular}{|l|l|}
\hline & Fresh Tilapia \\
\hline
\end{tabular}




\begin{tabular}{|c|c|c|c|c|}
\hline \multirow{2}{*}{} & \multicolumn{2}{|c|}{ Acceptable } & \multicolumn{2}{c|}{ Unacceptable } \\
\cline { 2 - 5 } & No. & $\%$ & No. & $\%$ \\
\hline Total viable count & 40 & $80 \%$ & 10 & $20 \%$ \\
\hline Coliform count & 28 & $56 \%$ & 22 & $44 \%$ \\
\hline S.aureus count & 47 & $94 \%$ & 3 & $6 \%$ \\
\hline $\begin{array}{c}\text { Total vibrio count } \\
\text { (MPN) }\end{array}$ & 50 & $100 \%$ & 0 & $0 \%$ \\
\hline Salmonella & 50 & $100 \%$ & 0 & $0 \%$ \\
\hline
\end{tabular}

EOS, 2009 for TVC, TC, S.aureus, Salmonella FDA 2002 b for Total vibrio

\section{DISCUSSION}

Sensory evaluation: The most appropriate analytical tool for evaluating freshness is sensory panel where each judge co-ordinates various received sensory inputs and outputs an integrated assessment. (Hanna, 1992). The sensory evaluation of the samples in this study revealed that all the examined fish were acceptable with varying degree of freshness were $13(26 \%), 28(56 \%)$ and $9(18 \%)$ of Grade E, A and B respectively (Table 1). The result agreed with that obtained by Amar (2001). The difference of grades may be attributed to the storage of fish at ambient temperature that cause rapid decrease in sensory quality (Gram, 1992) because of the microbial activities which create undesirable changes like off-flavors, texture and appearance (Johnston et al., 1994).

TVC is useful as an indicator of the condition and length of storage of products. (ICMS, 1986) stated that most aquatic animals at the point of harvest have TVC in range of $10^{2}-10^{5}$ which may increase to $10^{6}$ in fresh water fish. In our study the TVC ranged from $2.5 \times 10^{2}$ to $4.6 \times 10^{8}$ with mean $4.2 \times 10^{6} \pm 0.002 \mathrm{cfu} / \mathrm{g} .80 \%$ of the samples were within the acceptable limit (Table 2 and 3 ) this limit was approved by (ICMSF, 1986; EOS, 2009). This result agreed with the results obtained by Benta et al. (1982); Mahmoud (1990); Morshdy (1992a); Amar (2001) who 
found the mean TVC were; $5.1 \times 10^{6}, 8.4 \times 10^{6}, 2.4 \times 10^{6}$ and $3.4 \times 10^{6} \mathrm{cfu} / \mathrm{g}$ respectively. An increase of TVC more than $10^{6} \mathrm{cfu} / \mathrm{g}$ is indicative of long storage at chilling temperatures, temperature abuse, unhygienic measures during handling and transportation (ICMSF, 1986) or the fish might be caught from polluted warm water (FAO, 1995).

Total coliforms: Coliform bacteria including Escherichia coli are considered as indicator bacteria for presence of contamination. The results obtained in this study (Table 2 and 3) revealed that TC were obtained in $74 \%$ of the examined fish with counts ranged from 0 to $6.1 \times 10^{4} \mathrm{cfu} / \mathrm{g}$ and mean $2.8 \times 10^{2} \pm 0.010,44 \%$ of the samples have TC above the acceptable limit permitted by (ICMS1986 and EOS 2009) and this increase may be either due to the contamination of fish in water or due to secondary contamination during handling or storage of fish using contaminated ice (Mandal et al., 2009). Our results agreed with that obtained by (Morshdy, 1992b) who found the mean TC was $4.8 \times 10^{2}$ and also agreed with (Jayasinch and Rajakaruna, 2005) who found that $73.4 \%$ of the samples have Coliforms and $40 \%$ were above the acceptable limit. Higher incidences were obtained by El_Zanfaly and Ibrahim (1982); Mhango et al. (2010) who detected coliforms in 100\% and $84 \%$ of the samples respectively. The variation of incidences may be attributed to the degree of water pollution from which the fish were caught, the possible temperature fluctuations, time taken during transporting and trading (Aranilewa et al., 2006).

Staphylococcus aureus: In Table 2 and 3 the incidence of S.aureus was $6(12 \%)$ with count ranged from 0 to $3.7 \times 10^{3} \mathrm{cfu} / \mathrm{g}$ and mean of $5.1 \times 10^{1} \pm 0.114$. Only $3(6 \%)$ of the samples have S.aureus count above the acceptable limit of ICMSF (1986) and EOS (2009) which is $\left(10^{3}\right.$ $\mathrm{cfu} / \mathrm{g})$. A higher incidence was achieved by Morshdy (1992b) who could detect S.aureus in $30 \%$ of the samples with mean count of $4.8 \times 10^{3} \mathrm{cfu} / \mathrm{g}$. Presence of S.aureus in fish indicates poor handling measures as S.aureus are found on the skin, nose and throat of most people especially people with cold an sinus infection (Bramsnacs, 1999). Ibrahim et al., (2009) concluded that fish sold in markets may represent a public health hazard as they could isolate S.aureus from Tilapia fish samples and hand swabs of fish handlers. Five coagulase positive S.aureus isolates could be isolated in our study which were further examined for their ability to produce enterotoxines and only four isolates were able to produce enterotoxin type B. Presence of food poisoning strains generally comes from human sources (Aggie-Horticulture, 2008). 
Salmonella spp.: Which is a food borne pathogen and its presence in food create a threat to man who consume this food and not be allowed by ICMSF (1986) EOS (2009). In this study Salmonella spp. have not been detected in all examined samples (Table 2 and 3). This result is similer with that obtained by Baker et al. (1983); Jayasinch and Rajakaruna (2005) but disagree with the result achieved by Mahmoud (1990); Darwish (1991); Amar (2001); Sanaa Yagoub (2009) who isolated Salmonella spp. from tilapia fish at different rates. Salmonella spp. are not a typical environmental contaminants but generally gain access to fish during handling (ICMSF, 1986) therefore presence or absence of Salmonella spp. depends on the surrounding contaminants.

Total Vibrio spp.: Vibrios naturally present in fresh water and marine environments and some are pathogenic to humans. Many of the pathogenic species, with the notable exception of Vibrio cholerae, are adapted to salt or brackish water habitats (Quinn et al., 2004). In the present study vibrio spp. was detected in $11(22 \%)$ of the examined samples with ranged count 0 to $4.6 \times 10^{2} \mathrm{MPN} / \mathrm{g}$ and mean $2.1 \times 10^{1} \pm 0.002$ MPN/g (Table 2 and 3). All the samples are within the acceptable limit approved by FDA $2002 \mathrm{~b}\left(\leq 10^{4} \mathrm{MPN} / \mathrm{g}\right)$. Higher incidences were obtained by Onuoha et al. (1995); Yücel; Balci (2010) who detected $52.3 \%$ and $37 \%$ of vibrio spp. in Tilapia fish respectively. The variation in incidence may be attributed to geographical and seasonal variation (FDA 2002b).

Heat treatment: Heat is the most practical and effective means to destroy microorganisms (Aggie-Horticulture, 2008). In this study fish was exposed to boiling water for 10 minutes The TVC and TC decreased to $<100 \mathrm{cfu} / \mathrm{g}$ and $<10 \mathrm{cfu} / \mathrm{g}$ respectively and none of the pathogenic bacteria (S.aureus, Salmonella spp. and Vibrio spp.) have been detected. The result line with Ehow (2011) which concluded that cooking foods at temperatures between $145-165^{\circ} \mathrm{f}$ ensures the destruction of bacteria; they also added that cooking food at high temperature for an extended time destroys all food borne bacteria.

\section{Conclusion and Public health significance:}

This study shows that the majority of examined fish samples sold in Port-Said fish market were of acceptable sensory and microbiological quality. Presence of some strains of enterotoxigenic S.aureus constitute a public health hazard to people who will consume that fish as it indicate a risk of Staphylococcal food poisoning. Food contaminated with S.aureus toxin can cause food intoxication after the organisms have been 
destroyed by heat (Bruce and Kermit, 2009). The symptoms of Staphylococcal intoxication occur within 2-4 hours with range of 30 minutes to 8 hours and symptoms are, nausea, vomiting, abdominal cramps, diarrhea, acute prostration and subnormal temperature during acute attack which may be elevated later (Ray 2004; Aggie-Horticulture 2008). Presence of Vibrio spp. may also constitute a risk to man consuming such fish especially if consumed raw or insufficiently cooked (Rapid Microbiology, 2007). Three species are considered to be important human pathogens $V$. cholerae, $V$. parahaemolyticus and $V$. vulnificus (Rapid microbiology, 2007). All three have the potential to be foodborne, and are most often associated with the consumption of raw, or undercooked. A number of other species have infrequently been isolated from the stools of people suffering from gastroenteritis and are considered to be occasional human pathogens. These include $V$. alginolyticus, $V$. fluvialis, $V$. furnissii, $V$. hollisae, $V$. metschnikovii and $V$. mimicus. $V$. cholerae is the cause of outbreaks and epidemics of cholera, a serious and potentially fatal gastrointestinal infection (Rapid Microbiology, 2007). V. parahaemolyticus is the species most likely to be associated with foodborne disease in humans. It can cause mild to moderate gastrointestinal infections, which are usually self limiting and rarely fatal. Pathogenicity is associated with a thermostable haemolysin, called the Kanagawa phenomenon. Almost all isolates from cases of food poisoning are Kanagawa positive strains (Rapid Microbiology, 2007). V. vulnificus is an occasional cause of serious infections, infections can take the form of gastroenteritis in healthy adults, but in vulnerable individuals the pathogen can cause primary septicaemia, which is very serious and has a mortality rate of more than $50 \%$ (Rapid Microbiology, 2007).

\section{REFERENCES}

Aggie-Horticulture (2008): Introduction to the Microbiology of Food. Food Processing Enterpreneurs. http://agie-horticulture-tamuedu.

Amar, M.A.M. (2001): Sanitary Assessment of some common Fresh water fish in Assiut. M.V.Sc. Thesis, Fac. Vet.Med. Assiut Univ., Egypt.

Aranilewa, S.T.; Salawu, S.O.; Sorungbe, A.A. and Ola-Salawu, B.B. (2006): Effect of frozen period on the chemical, microbiological and sensory quality of frozen tilapia fish (Sarotherodun galiaenus). Nutr. Health, 18(2): 185-192. 
Aquatic Animal Research Center Charoepokphand (1999): Tilapia fish culture. Food Agriculture Organization of the United Nations. Rome, Italy, Technical paper (Leaflet) $6 \mathrm{p}$.

Baker, D.A.; Smitherman, R.O. and McCaskey, T.A. (1983): Longevity of Salmonella typhimurium in Tilapia aurea and water from poolsfertilized with swine waste. Appl. Environ. Microbiol., 45(5): 1548-1554.

Binta, G.M.; Tjaberg, T.B.; Nyaga, P.N. and Valland, M. (1982): Market fish hygiene in Kenya. J.Hyg. Camb, 89(1): 47-52.

Bramsnacs, F. (1999): Handling of Fresh Fish. (Borgstromc edit.). Fish as Food. Arnord publishers.

Bruce, A.G. and Kermit, D.H. (2009): CBRNE - Staphylococcal Enterotoxin B. http://emedicine.medscape.com

Darwish, A.M. (1991): Salmonellae in Lates niloticus fish. Vet. Med. J. Giza, 39(1): 13-19.

Ehow (2011): The Effects of Temperature on Foodborne Bacteria. http://eHow.com

EOS "Egyptian Organization for Standardization and Quality" (2009): Whole fish. No. 889-1/2009.

El-Zanfaly, H.T. and Ibrahim, A.A. (1982): Occurrence of bacterial pollution indicators in Boulti (Tilapia nilotica Linn.) Fish. Ernährungswiss 19: 163-165.

FAO (1995): Quality and Quality Changes in Fresh Fish. pp 38-41 (Huss, H.H. Edit.) FAO fisheries technical paper No.38.

FDA (2001a): BAM, Aerobic Plate Count. Bacteriological Analytical Manual, Edition 8, Revision A, 1998. Chapter 3. Authors: Larry Maturin and James T. Peeler

FDA (2001b): BAM, Staphylococcus aureus. Bacteriological Analytical Manual, 8th Edition, Revision A, 1998. Chapter 12. Authors: Reginald W. Bennett and Gayle A. Lancette.

FDA (2002a): BAM, Enumeration of Escherichia coli and the Coliform. BacteriaBacteriological Analytical Manual, $8^{\text {th }}$ Ed., Revision A, 1998. Chapter 4. Authors: Peter Feng, Stephen D. Weagant, Michael A. Grant

FDA (2002b): Fish and fisheries products hazards and controls guidance, third edition". Retrieved on 14 October.

FDA (2004): BAM Vibrio. Bacteriological Analytical Manual, 8th Ed. Revision A, 1998. Chapter 9. Authors: Charles A. Kaysner and Angelo DePaola, Jr. 
FDA (2007): BAM, Salmonella. Bacteriological Analytical Manual, $8^{\text {th }}$ ed., Revision A, 1998. Chapte5. Authors: Wallace H. Andrews and Thomas.Hammack.

Gram, L. (1992): Seafood Science and Technology $1^{\text {st }}$ ed.: 225-238 (Bligh E.C. edit.) Canadian Institute of fisheries technology, Canada.

Hall, G.M. (1992): Fish Processing Technology. $1^{\text {st }}$ ed., Chapman and Hall. USA.

Hanna, J. (1992): Rapid Microbiological methods and Fresh Fish Quality Assessment. In Fish Processing Technology $1^{\text {st }}$ ed.: 275-281 (Hall, G.M. edit.). Chapman and Hall, New York.

Ibrahim, M.A.; Abdel-Ghany, A.E.; Emeash, H.H.; Nahed, H.G. and Gihan, K.A.L. (2009): Epidemiological studies on the role of fish in transmitting some zoonotic diseases to man. Vet. Med. J. Giza, 57(2): 169-185.

ICMSF (1986): Microorganisms in Foods. 2- Sampling for microbiological analysis: Principles and specific applications. $2^{\text {nd }}$ ed. Univ. of Toronto Press, Toronto, Canada.

Jayasinchi, P.S. and Rajakaruna, R.M. (2005): Bacterial contamination of fish sold in Fish Markets in the central Provice of Srilanka. J. Natn. Sci. Foundation Srilanka, 33(3): 219-221.

Johnstone, W.A.; Nicholson, F.J.; Roger, A. and Stroud, G.D. (1994): Freezing and Refrigerate storage in Fisheries. FAO Fisheries Technical paper No. 334 .

Leung, C.; Huang, Y. and Pancorbo, O. (1990): Bacterial flora associated with a Nigerian freshwater fish culture. Journal of Aquaculture in Tropics, 5: 87-90.

Mahmoud, Y.E.A. (1990): Studies on the sanitary condition of some Nile fishes marketed in Kalyobia Governorate. M.V.Sc. thesis, Vet. Med., Moshtohor Zagazig Univ. Benha Branch, Egypt.

Mandal, S.C.; Hasan, M.; Rahman, M.S.; Manik, M.H.; Mahznud, Z.H. and Sirajul-Islam, M.D. (2009): Coliform Bacteria in Nile Tilapia, Oreochromis niloticus of shrimp- Gher, pond and fish market. World J. of Fish and Marine Sci. 1(3): 160-166.

Mhango, M.; Mpuchane, S.F. and Gash, B.A. (2010): Incidence of indicator organisms, opportunistic and pathogenic bacteria in fish. African J. of Food, Agriculture, Nutrition and Development, 1(3): 216-221.

Morshdy, A.M.A. (1992a: Hyginic Studies on Fishes of Manzala Lake. Zag. Vet. Med. J., 20(5): 701-704. 
Morshdy, A.M.A. (1992b): Food poisoning microorganisms in fishes of Manzala lake. Zag. Vet. J., 20(5):709-712.

Onuoha, G.C.; Adokl, A.; Erondu, E.S. and Nduka, E.C. (1995): Microbial profile of organically enriches freshwater ponds in south- eastern Nigeria. Int. J. Of Environmental Studies, 48(3): 275-282.

Pulella, S.; Fernandes, C.; Flick, G.J.; Libey, G.S.; Smith, S.A. and Coale, C.W. (1998): Indicative and pathogenic microbial quality of aquacultured finfish grown in different production systems. Journal of Food Protection, 61: 205-210.

Quinn, P.J.; Carter, M.E.; Markey, B. and Carter, G.R. (2004): Clinical Veterinary Microbiology, $3^{\text {rd }}$ ed. Elsevier Publisher, UK.

Ray, B. (2004): Fundamental Food microbiology $3^{\text {rd }}$ ed. New York: CRC Press.

Ramos, M. and Lyon, W.J. (2000): Reduction of endogenous bacteria associated with catfish fillets using the grovac process. Journal of Food Protection, 63: 1231-1239.

Rapid Microbiology (2007): Detection and Identification of Vibrio spp. in Food. http:// WWW. rapid microbiology. com

Romana-Eguia, M.R.R. and Eguia, R.V. (1999): Growth of five Asian red tilapia strains in saline environments. Aquaculture, 173: 161-170.

Sanaa O. Yagoub (2009): Isolation of Enterobacteriaceae and Pseudomonas spp. from raw fish sold in fish market in Khartoum State. J. of Bacteriology Research, 1(7): 85-88.

Yücel, N. and Balci, S. (2010): Prevelance of Listeria, Aeromonas and Vibrio species in fish used for human consumption in Turkey.J. Food Prot., 73(2): 380-384. 